\title{
Reklamlarda Toplumsal Sinif: Otomobil Reklamları Üzerinden Bir Söylem Analizi
}

\author{
Süheyla Ayvaz (Arş. Gör.) \\ Selçuk Üniversitesi İletişim Fakültesi \\ suayvaz@gmail.com \\ Orcid: 0000-0002-1065-592X \\ Tuba Livberber (Arş. Gör. Dr.) \\ Selçuk Üniversitesi İletişim Fakültesi \\ tubalivberber@windowslive.com \\ Orcid: 0000-0002-9879-2135
}

Başvuru Tarihi: 28.01.2019

Yayına Kabul Tarihi: 29.03.2019

Yayınlanma Tarihi: 22.07.2019

DOI: 10.17680/erciyesiletisim.518553

Ayvaz, S. ve Livberber, T. (2019). Reklamlarda Toplumsal Sınıf: Otomobil Reklamları Üzerinden Bir Söylem Analizi. Erciyes İletişim Dergisi, 6 (2), 1141-1164. DOI: 10.17680/erciyesiletisim.518553

\section{Öz}

Toplumsal sınıf; toplum içerisindeki bireylerin ekonomik, sosyal ve kültürel iyeliklerinin nicel durumuna göre hiyerarşik olarak bölünmesine/gruplaşmasına işaret etmektedir. Medya da kültürel ürünler aracılığıyla bu grup çıkarlarının meşrulaştırılması ve desteklenmesine yardımcı olan fikir ve inançları simgeleyen ideolojik söylemleri inşa etmektedir. Reklam metni bu bağlamda tüketiciye özerk nesneler olarak seslenmekte ve sahte ihtiyaçlara kültürel yan anlamlar ekleyerek nesneleri simgesele indirgemektedir. Böylece reklamlardaki kodlar aracılığıyla belirli bir yaşam tarzı ve dolayısıyla sınıf atlama ya da sınıfsal bir konuma sahip olma pratiği üretilmekte ve yeniden üretilmektedir. Bu ana eksenden yola çıkan araştırmada, ideolojik yaklaşım çerçevesinde reklam metinlerinin çözümlenmesi amaçlanmıştır. Renault, Jetta ve Opel'in toplumsal sınıf temalı birer reklam filmi araștırmanın inceleme nesnesi olarak belirlenmiştir. Reklam metinleri, Van Dijk'ın eleştirel söylem analizi yöntemi kullanılarak çözümlenmektedir. Çalışma sonucunda analiz edilen reklam filmlerinin senaryo açısından öncelikli temasının üst orta sınıf vurgusu olduğu görülmüştür. Bunun yanı sıra karakterlerin giyiminden konumlanışına, mekanların düzenlenmesinden kullanılan nesnelere kadar bütünüyle aynı sınıfa ait yaşam tarzı betimlemelerinin yer aldığı gözlemlenmiştir.

Anahtar Kelimeler: İdeoloji, Toplumsal Sınıf, Reklam, Söylem Analizi, Hayat Tarzı. 


\title{
Social Class in Advertising: A Discourse Analysis in Automobile Ad
}

\author{
Süheyla Ayvaz (Res. Asst.) \\ Selçuk Üniversitesi İletişim Fakültesi \\ suayvaz@gmail.com \\ Orcid: 0000-0002-1065-592X \\ Tuba Livberber (Res. Asst. Ph.D.) \\ Selçuk Üniversitesi İletişim Fakültesi \\ tubalivberber@windowslive.com \\ Orcid: 0000-0002-9879-2135
}

Date Received: 28.01.2019

Date Accepted: 29.03.2019

Date Published: 22.07.2019

DOI: 10.17680/erciyesiletisim.518553

\section{Abstract}

The media builds ideological discourses that symbolize ideas and beliefs that help to legitimize and support these group interests through cultural products. The ad text in this context calls consumers as autonomous objects and degrades objects to icons by adding cultural connotations to fake needs. Thus, by means of codes in advertisements, the practice of having a particular lifestyle and hence a class jump or class position is produced and reproduced. In this study, which is based on this main axis, it is aimed to analyze advertisement texts within the framework of ideological approach. Renault, Jetta and Opel's social class-themed advertising film were identified as the object of research. Ad texts were analyzed using Van Dijk's critical discourse analysis method. As a result of the study, it was observed that the priority theme of the analyzed commercial films was the upper middle class emphasis in terms of the scenario. In addition, it has been observed that lifestyle depictions of the same class are also reflected in from costumes to positions of characters and the design of spaces from the position of used objects.

Keywords: Ideology, Social Class, Advertisement, Discourse Analysis, Life Style. 


\section{Giriş}

Reklamlar, Williamson’ın da (2001: 11) belirttiği gibi “Açıkça özerk bir varoluşa ve muazzam etkileme gücüne sahip bir üstyapıyı oluşturur." Burjuva tüketim kültürü için merkezi bir önem taşıyan olan reklam metni, insanları sahip olmaları zorunlu çeşitli ürünlerden haberdar eder. Arz duygusu yaratır, tarz duygusu verir, imaj yaratmak için hangi metaların kullanacağı hakkında bilgilendirme yapmaktadır (Berger, 2014: 63). Sadece bunu yapmakla kalmaz, günümüzde reklamın en önemli konusu insanları aslında almayabilecekleri, almadan da hayatlarını idame ettirebilecekleri şeyleri almaya yöneltmektir (Ritzer, 2011: 85). Bu bağlamda günümüz tüketicisi göstergelerin tüketicisidir. Reklamcılık, tüketicinin sınıfsal konumunun sembolik öğelerini yansıtacak olan ürün ya da hizmetlerin neler olduğu hakkında bilişsel bir öğreti ve ikna işlevi yerine getirmektedir. Tüketici, hangi ürünlerle ve (bu çalıșma özelinde) nesnelerle hangi sınıfa ait olacağını ve o sınıfın yaşam tarzının neler olduğu bu yolla öğrenmektedir.

Çalışmada, reklamlar aracılığıyla inşa edilen toplumsal tabakalaşmanın sınıfsal izleğini ortaya koymak için öncelikle toplumsal sınıf kavramsallaşmasının sosyolojik anlamda geçirdiği süreç, literatür bölümünde açıklanacaktır. Toplumsal sınıf kavramsallaștırmasının öncelikli isimlerinden Marx ve Weber'in teorilerine ve ekonomik belirlenimcilik teorisinin kültürel alanı ihmal ettiği gerekçesini savunan teorisyenlerin görüşlerine yer verilecektir. Hemen arkasından çalışma için önem arz eden Bourdieu'nın toplumsal sınıf kavrayışının tanıtımı yapılacaktır. Daha sonra van Dijk'ın söylem analizi anlatılarak bu çalışma özelindeki uyarlanış şekli belirtilip reklam filmlerinin çözümlemesine girişilecektir.

\section{Marx'tan Bourdieu'ya Toplumsal Sinıf Meselesi}

Marx'a göre (1990: 773) bir sınıfı oluşturan şey; gelirlerin ve gelir kaynaklarının özelliğiyle ilgilidir. Üyelerinin emek gücü, sermaye ve toprak mülkiyeti ile ücret, kar ve toprak rantı elde etmesine göre toplumsal sınıflar kategorize edilmektedir. Marksist yaklaşım, sınıfların bu iyeliklerini tarihsel evrimi açıklamada kullanmaktadır. Bütün toplumların tarihini, sınıf savaşım tarihi olarak tasvir etmekte (Marx ve Engels, 1976: 103); ezilen ve ezilenler arasındaki mücadeleleri tarihin oluşumunda dinamo olarak görmektedir. Bu bağlamda tarihsel materyalizm olarak kavramsallaştırılan, tarihin ekonomikilişkiler tarafından belirlen diği savı, kabaca yöneten ve yönetilenlerin sahip oldukları maddi sermayenin niteliğine-niceliğine dayanmaktadır. Peffer'ın (2001: 35), altını çizdiği gibi, Marx'ın temel iddiası artı ürünü elde etmek için sınıflar arası mücadelenin tarihi inşa ettiğidir. Smith'in (2007: 20) belirttiği gibi, bina metaforunu kullanan Marx için, binanın temelinde ekonomik ilişkiler diğer bir ifadeyle üretim tarzı, üretim ilişkileri ve üretim araçlarının bulunduğu 〈altyapı〉, kültürü bir başka deyişle politika, hukuk ve ahlak gibi unsurlardan oluşan üstyapıyı belirlemektedir. Marx'ın bu tarihsel materyalist anlayışının özünde ekonomik ilişkilerin egemen ideolojiyi oluşturduğu varsayımı yatmaktadır. Bu anlamda toplumsal sınıf kavramı, üretim ilişkilerinin tesis ettiği toplumsal tabakalaşmaya gönderme yapmaktadır.

Ortodoks Marksizm'ine göre Sanayi Devrimi'yle birlikte modern toplum işçi sınıfı, burjuva sınıfı ve küçük burjuvazi olmak üzere üç ana sınıfa ayrılmak zorunda kalmıştır. Bu sonuç, tüm toplumlar nezdinde aynı kabul edilmiştir. Sermaye ve emek aidiyeti üzerinde temellenen bu sınıfsal yaklaşımda burjuvazi, kapitalist toplumda 'üretken zenginliğin sahibi' olan yönetici sınıfı işaret ederken, proletarya kendi 
emeğini yönetici sınıfın çıkarları için satan ve ancak bu şekilde kendi yaşamını sürdüren bağımlı bir sınıfı ifade etmektedir (Heywood, 2015: 134). Küçük burjuvazi ise işçi sınıfı ve burjuva sınıfı arasında durmadan 'yalpalayan' ve kendini yenileyen (Marx ve Engels, 1976: 122-123); "kendi hesabına çalışan esnaf ve zanaatkarlar ile serbest çalışan avukat, doktor, eczacı, mühendis, muhasebeci, sanatçı ve devlet memurları" gibi meslekleri icra eden bireylerden oluşan geleneksel orta sınıfı (Aslan, 2012: 59) kapsamaktadır.

Bu sınıf yaklaşımında burjuva sınıfı, işçi sınıfının ürettiği artı ürünü çekip alan sömüren sınıf olarak betimlenmektedir. Böylece egemen sınıf, iş̧̧inin emeğini meta değerine indirgeyerek değiş tokuş etmektedir. Burjuvazi feodal, ataerkil, romantik ilişkilere son vermekle kalmayıp insanlar arası ilişkileri maddi çıkara bağımlı hale getirmiş ve doktor, avukat, bilim adamı gibi meslekleri kendi ücretli emekçisine dönüştürmüştür (Marx ve Engels, 1976: 105). Bununla birlikte kapitalist sistemde işçi emeği, kullanım değeri farklı olan metalar için bile aynı miktarda harcanmış varsayılmaktadır. Eagleton'ın ifadesine göre (2015: 169) mübadele değeri olarak kavramsallaştıran bu açıklamada kullanım değerlerine sahip iki metanın, aynı miktarda soyut emek içerdiği varsayılıp bunların eşit bir biçimde mübadele edilmesini söz konusudur. Daha açık bir ifadeyle, kullanıldığında farklı faydalar sağlayan metaların üretiminde harcanmış emek gücü, piyasa altında 'aynıymış gibi' kabul edilip aynı fiyata satılabilmektedir. $\mathrm{Bu}$, mübadele değerinin piyasa koşulları altında emeğin ölçüsüz soyutlanmış eşitliğini yansıtır. Böyle bir analiz içerisinde, oy veren vatandaşların eş değer kabul edilmesinin aslında onların eşitliğini gizlemesi durumunda olduğu gibi, gerçekte emeğin sömürülmesinin gizlenmesi yönünde bir mistifikasyon işlemi bulunmaktadır.

Mistifikasyon, Marksist yaklaşımın ideolojiyi tanımlama biçiminde öne çıkan bilincin yanlış yönlendirilmesi vurgusunu içermektedir. Tüm sınıfsal 'gerçekliğin' bu yanlış bilincin başka bir ifadeyle ideolojinin bir ürünü olduğunu ekonomik ilişkilere bağlı açıklayan düşünceye göre, egemen ideoloji toplumun düşünsel sınırlarını çizmekte, sınırlandırmakta ve en önemlisi kurmaktadır. Bu doğrultuda Marx ve Engels'e göre (1976: 44-45) toplumun maddi gücünü (üretim araçlarını) elinde bulunduran sınıf olarak egemen sınıf, aynı zamanda toplumun egemen zihinsel gücüdür. Çünkü egemen sınıf, sadece alt yapının araçlarını değil, aynı zamanda üst yapının açarlarını ('zihinsel-bilişsel üretim araçlarını) ve onları denetleyebilme gücünü de elinde bulundurmaktadır. Düşünce üreticileri olarak hakimiyet kuran egemen sınıf, kendi ideolojisini hem üretmekte hem de bunların yayılmasında başat bir rol oynamaktadır.

Toplumsal sınıfların zihinsel durumunu üretim ilişkilerini önceleyerek açıklayan bu paradigma, üst yapının/kültürün ihmal edildiği gerekçesiyle bazı eleştiriler almış ve geliştirilmiştir. Öncelikle Weber (1999), toplumsal sınıfların evrenselliğini sorgulamış ve bir toplumun kültürünün onun sınıfsal yapısında belirleyici olduğunu savunmuştur. Ona göre kapitalizm, Batı'nın Protestan Ahlakı'nın; çilecilik, çalışkanlık, basiret ve tutumluluğu öğütleyen Protestan Ahlakı'nın (Featherstone, 2013: 198) bir sonucudur. Weber (1978: 302-306) toplumsal sınıf ve toplumsal statü kavramlarını birlikte kullanır. Ona göre, toplumsal sınıf üç farklı şekilde kategorilendirilmektedir. İlki özel mülk sahipliği farklılı̆̆ına göre belirlenen köle/çalışan, toprak, tesis (fabrikalar ve ekipman), gemi, menkul klymetler sahipliği ya da alacaklı (hayvancılık, tahıl veya para) olma halini içeren mülk sınıfıdır. Íkincisi özel mülk farklılıklarına göre belirlenen tüccarlar, gemi sahipleri, sanayi ve tarım girişimcileri, bankacılar ve 
finansörler, bazen de aranan uzmanlığa veya ayrıcalıklı eğitime sahip profesyoneller (avukatlar, doktorlar, sanatçılar gibi) ve teknisyenleri içeren ticari sınıftır. Üçüncüsü ise sınıflar arası hareketliliğe uyun olan, mülkiyet ve eğitim yoluyla ayrıcalıklı hale gelmiş, yetenekli aydınları ve uzmanları (beyaz yakalılar- memurlar) kapsayan sosyal sınıf olan orta sınıftır. Weber sosyal statü kavramını kullanarak sınıflar arası geçişlilikte ve sınıf içi farklılaşmaya ayrı bir pencere açmıştır. Onun için yaşam tarzı, resmi eğitim, kalıtsal ya da mesleki prestij ve tüketim kalıpları gibi öğeler ayrı sınıfların bireylerinde ortak olabilir. Bu yüzden onun nezdinde 'kültürel aynılık/ benzerlik' ekonomik sınıfçılıktan daha önemli bir kıstastır.

Daha sonra Batı Marksizm'i teorisyenleri ekonomik belirlenimcilik vurgusunu reddederek sınıfsal mücadeleyi kültürel boyuta taşıyacak hamlelerde bulunmuștur. Lukacs (1998: 55, 105), Marksist teorinin sınıf bilincine yönelik geliştirdiği pejoratif vurgudan kaçınarak işçi sınıfının bilincini onun ahlakı olarak tanımlamıştır ve teori ile pratiğe devrimci bir işlev atamıştır. Onun için işçi sınıfının bilinci, tarihin hem öznesi hem de nesnesi olmak bakımından olumlu bir yerdedir ve devrimin gerçekleşmesi ona bağlıdır. Dolayısıyla şu anda yanlış olarak tasavvur edilen bilinç aslında geleceğin potansiyelini içinde büyütüyor olabilir. Çünkü işçi sınıfı ve burjuva sınıfı birbirinin değili olduğunu daha açık bir ifadeyle biri olmadan diğerinin olmasının mümkün olmadığını savunmaktadır. Egemen ideolojinin yaygınlığını ise Marx'tan daha ileri bir safhaya taşıyarak 'șeyleşme' kavramı ile ifade eder. Eagleton'ın açıklamasına göre (2011: 274) şeyleşme; Marx’ın meta fetişizmi doktrininden türemiş ve toplumsal yaşamanın bütününe meta biçiminin nüfuz etmesi anlamına gelmektedir. "İnsan deneyiminin (bütünüyle) ve yaygın bir şekilde insanlıktan çıkartılması, nicelikselleştirilmesi ve makineleştirilmesi şeklini" alması şeyleşmenin mantığını oluşturur.

Gramsci'ye gelince o, sınıfların kültürel yeniden üretimini için hegemonya kavramına başvurmuştur. Hegemonya ideolojinin rızaya dayalı üretimi anlamını içermektedir. Sancar'a göre (2014: 31-46) hegemonya, iktidarın zor kullanarak ideolojik ekimi gerçekleştirmek yerine sivil toplum aracılığıyla öznelerin onayına dayalı ideoloji inşasını kapsamaktadır. Gramsci için ideoloji; Marx'ın öngördüğü biçimde sadece üst yapının bir unsuru olmaktan ziyade hegemonik araçlar sayesinde (felsefi, edebi, sanatsal vb.) üst yapı ve alt yapı arasındaki uyumu sağlayan bir mekanizmadır. Bu açıdan Gramsci ideolojiyi toplumsal sınıfların 'dünya görüşü' olarak ele almaktadır. Denilebilir ki Gramsci sınıflara ait statik bir ideoloji açıklamasının yerine eyleme bağlı dinamik bir ideoloji kurgulamıştır. İdeolojiyi her gün yeniden ve yeniden üretilen bir tanıma ulaştırmıştır.

Bunun yanında iletişim araștırmalarında eleștirel teori bağlamında sıklıkla adı yad edilen Althusser (2014), 'devletin ideolojik aygitları' teziyle, kültürün mekânı üst yapının sınıfsal icrasını 'çağırma' kavramıyla ilişkilendirerek, bireylerin özneye dönüşüm sürecini dolayısıyla sınıf aidiyetini belirli kurumlara bağlamıştır. Dini kurumlar, okul, aile, hukuki kurumlar, politik kurumlar, sendikal kurumlar, enformasyon araçları (kitle iletişim araçları) ve edebiyat/güzel sanatlar gibi kültürel aygıtların, egemen ideolojinin yeniden üretimini sağladığını belirtir (bkz. s. 50-51). ${ }^{1}$ Böylece dil, ideolojinin kültürel üretiminde merkezi bir konuma taşınmıştır. Bu açıdan Foucault da benzer şekilde dilin ideolojik söylem üretiminde kilit bir rol oynadığını savunmaktadır. Ancak o dili bir iktidar aracı olarak görmektedir. Bilimsel alanda konuşanlar, bölücü pratikler (deli-akıllı gibi) ve insanın kendisini özneleştirmek 
adına kendi kendini tanımlamasında araç olan ifadeleri bir iktidar aracı olarak değerlendirmiştir (Çelebi, 2013: 519-520).

Bourdieu ise sınıflı bir beden tasviri yaparak bedenin kültürel üretimine vurgu yapmıştır. Ona göre sınıflı beden; iktisadi sermaye, kültürel sermaye, sosyal sermaye ve sembolik sermaye gibi dört adet sermaye türüyle maddileşmektedir. İktisadi sermaye, sahip olunan para ya da özel mülk gibi maddi mülkleri (Bourdieu, 1986: 46-49); kültürel sermaye, entelektüel birikim/yetkinlik ya da eğitim firsatına sahip olmak gibi kültürel mülkleri; sosyal sermaye, tanışıklıklar ya da ilişkiler gibi sosyal mülkleri ve son olarak simgesel/sembolik sermaye ise meşruluğu bir bakıma diğer sermayeleri de kapsayan ve aynı zamanda diğer sermayelerin algılanmasını sağlayan mülklerdir (Işık, 1998: 138). Bu açıdan beden, sınıfsal konumların algılanmasına ve gösterilmesine hizmet eden bir mekân olarak karşımıza çıkmaktadır. Peki, bu nasıl gerçekleşmektedir? Bourdieu'ya göre bedenin gösterimi ve farklılaşmasının temel nedeni beğenidir. Ona göre toplumsal sınıfların maddi dünyadaki temsili beğenilerin ayrıștırıcı pratiğinde gizlidir. Demez'in ifade ettiği üzere (2009: 20) bireyin bir başka gruba dahil olmasını ya da o gruptan farklılaşmasını sağlayan beğenidir. Sınıflama mantığı tüm alanlardaki seçimlerimiz, beğeni yargımızın işlerliği sonucunda işlemeye devam etmektedir (Işık, 1998: 142). Örneğin bir işçinin yediği yemekten siyasal kararları ve bunları yapma biçimi tümüyle onun sınıfsal konumuyla ilişkilidir ve bir fabrika sahibininkilerden oldukça farklıdır (Bourdieu, 1995: 23). Beslenme, toplumsal cinsiyet rolleri, sofra düzeni (Köse, 2016: 178), oturuş tarzl, ellerin duruşu, mobilya, dekor, iskemle, bunları kullanma tarzı (Demez, 2009: 21) gibi pratikler ve maddi seçimler bütünüyle toplumsal sınıfın bedende görünür olmasına neden olmaktadır.

\section{Araştırmanın Metodolojisi}

Çalışma "Reklamlar nesneleri, toplumsal sınıf atlama aracı olarak hangi görsel ve dilsel unsurlarla birlikte bir ideolojik söylem içerisinde inşa eder?" sorusundan yola çıkmaktadır. Çalışmanın amacı bu soru doğrultusunda televizyonda yayınlanan reklamların, ideolojik bir söylem pratiği içerisinde, otomobile bağlı olarak inşa ettiği toplumsal sınıf kurgusunu ortaya koymaktır. Mevcut literatürde reklam metnine yönelik eleştirel söylem analizi çalışmaları yapılmış olsa da bunlar genellikle bir reklam filmini oluşturan bileşenleri tek tek ele almayıp daha çok reklam filminin genel anlatısı üzerine odaklanmaktadır. $\mathrm{Bu}$ açıdan çalışmada, haber söylemini yapısal olarak parçalayıp çözümlemeye girișen ve sonucunda bir model ortaya koyan van Dijk'in izleğinden hareketle reklam filmleri, onu oluşturan yapılara ayrılarak analiz edilecektir. Haberlerin eleștirel olarak analizini gerçekleștirmek üzere van Dijk'ın ortaya koyduğu eleştirel söylem analizi, yazılı medya metinlerinin sistematik çözümlenmesini kapsamaktadır (Sözen, 2014: 87): 
Tablo 1: van Dijk'ın Söylem Analizi Sistematiği

\begin{tabular}{|l|l|}
\hline A) Makro Yapılar & B) Mikro Yapılar \\
\hline 1. Tematik çözümleme & 1. Sentaktik Çözümleme \\
a. Başlık/lar (Üst başlık, Başıı, Alt başlık) & a. Cümle Yapılarının Etken ya da Edilgen Olması \\
b. Haber Girişi & b. Cümle Yapılarının Basit ya da Karmaşık Olması \\
1. Spot/lar & c. Cümle Yapılarının Uzun ya da Kısa Olması \\
2. Spot olmadığı zaman haber metninin ilk & 2. Bölgesel Uyum \\
paragrafı alınmalıdır. Haber tek paragraftan & a. Nedensel İlişki \\
oluşuyorsa ilk cümle haber girişi olarak alınabilir. & b. İşlevsel İlişki \\
c. Fotoğraf & c. Referansal İlişki \\
2. Şematik çözümleme & 3. Sözcük Seçimleri \\
a. Durum & 4. Haber Retoriği \\
1. Ana Olayın Sunumu & a. Fotoğraf \\
2. Sonuçlar & b. İnandırıcı Bilgiler \\
3. Ardalan Bilgisi & c. Görgü Tanıklarının Ifadeleri \\
4. Bağlam Bilgisi & \\
b. Yorum & \\
1. Haber Kaynakları & \\
2. Olay Taraflarının Olaya Getirdikleri Yorumlar & \\
\hline Kaynak: Ozer, O. (2011). Haber Söylem Ideoloji. Konya: Literatürk, S. 85. \\
\hline
\end{tabular}

Tablo 1'de görüldügü gibi van Dijk, haber metnini tek tek parçalarına ayırmış ve böylelikle haber söyleminin ideolojik içeriğini açığa çıkarmak için bir tümevarım yöntemi ortaya koymuştur. Makro yapıda van Dijk, haberin girişini oluşturan baskın parçaların tematik çözümlemesini; olayın arkaplan bilgisindeki ideolojik imalara ulaşmak için ise şematik çözümleme yolunu önermektedir. Mikro yapıda ise tamamen dilin yapısal inşasındaki gizil ideolojik nüvelere odaklanmayı sağlayacak bir çözümleme yöntemini sunmaktadır. van Dijk'in kullandığı bu yöntem, diğer medya metinlerine de uyarlanabilmektedir. Birer medya metni olarak ele alınabilecek reklam filmlerinin analizinde de eleştirel söylem yöntemi kullanılabilir. Bunun için "içinde hikaye unsuru bulunduran (anlatısal) reklam metinlerini" (Akt: Yllmaz 2017: 694) birer anlatıtürü olarak ele alarak reklam metninde ne anlatıldığına (öykü) ve nasıl anlatıldığına (söylem) odaklanmak amacıyla öyküleyici reklam filmlerinin (Yılmaz 2017: 693) bileşenleri reklam söyleminin makro ve mikro yapıları kapsamında değerlendirilmiștir. Bir reklam filmi senaryo, uzam (mekân), karakterler/oyuncular, özel efektler, ayrıntı çekimler, kostüm, dekor, ürün, ses, hareket, aksesuar-nesneler, renk, packshot, slogan, diyalog/monolog vb. bileşenlerden oluşmaktadır (Özgür, 1996: 234-235; Yolcu: 2001). Bu bağlamda Tablo 2'de görüldüğü üzere reklam filmlerinde senaryo, slogan, mekân, karakterler ve toplumsal/kültürel/sınıfsal bağlam toplumsal gruplar arasındaki güç, egemenlik ve eşitsizlik gibi makro analiz düzeyini/reklamın temasını yansıtmaktadır. Ayrıca reklam filminde kullanılan cümle yapıları, sözcük çekimleri, çekim tipi, müzik/jingle-ses-ses efektleri toplumsal düzenin mikro düzeyine ait dil kullanımı, söylem, sözlü etkileșim ve iletişimi daha genel anlamda reklam filminin retoriğini ortaya koymaktadır (van Dijk, 2015: 468). Reklam filmlerinin incelenmesinde kullanılacak eleștirel söylem analizi yöntemi bu çalışma özelinde aşağıdaki gibi uygulanacaktır.

Tablo 2: van Dijk’ın Söylem Analizi Modeli'nin Televizyon Reklam Filmine Uyarlanması

\begin{tabular}{|l|l|}
\hline A) Makro Yapılar & B) Mikro Yapılar \\
\hline 1. Senaryo & 1. Cümle Yapıları ve Sözcük Seçimleri \\
2. Slogan & 2. Çekim Tipi \\
3. Mekân & 3. Müzik/Jingle- Ses- Ses Efektleri \\
4. Karakterler & \\
5. Toplumsal/Kültürel/Sınıfsal Bağlam & \\
\hline
\end{tabular}


Çalışmada otomobil sektörünün seçilme nedeni Lefebvre'nin (2007: 115-120) otomobil nesnesine biçtiği ideolojik anlamdan kaynaklanmaktadır. Ona göre otomobil, modern gündelik hayatta "Kral-Nesne-Klavuz-Şey" olmakla birlikte kent ve mekânı düzenlemekte, toplumsal hayatta hiyerarşilere yol açmakta ve toplumsal sınıf ile statünün bir sembolüdür. Otomobil anlatısını reklama bağlayarak devam ettiği satırlarda Lefebvre (bkz. s. 119) reklamı "bir meta dili" olarak tanımlayarak "değişime sokulan nesne ile değişim değerinin varoluş tarzı» olarak açıklamaktadır. Reklam ve otomobil arasındaki bu bağlantı çalışma açısından çıkış noktası olarak kabul edilmiş ve bu sebeple toplumsal sınıf açısından sembolik bir anlam kazanan otomobil sektörü reklamları çalışmaya evren olarak seçilmiştir. Cengiz'e göre (2005: 45-50, 263-277) otomobil ilk icat ettiği yıllarda her ne kadar burjuva sınıfının lüks tüketim nesnesi olsa da 1920 'li ylllarda fantezi olarak bile olsa kitlesel tüketim nesnesi halini almıștır. Daha sonra 1930'lu yıllarda daha geniş kesimlere otomobil satın alma olanağı doğmuş ancak 1950'li yıllarda hala gösterişli ve konforlu bir otomobil üst sınıfın tekelindedir. 1960 'l y yllar itibariyle otomobil tüketimi hızla yayılırken günümüzde "herkes" için bir otomobil bulunmaktadır. Fakat otomobilin markalara göre simgesel değerleri değişmekte; bir taraftan bir otomobil markası halk arabası olarak diğeri gençlik isyanının sembolü olarak görülürken diğer taraftan bir otomobil markası belirli bir toplumsal sınıfın göstergesi olarak öne çıkmaktadır. Bu doğrultuda şimdiye kadar televizyonda yayımlanmış tüm otomobil reklamlarının eleştirel söylem analizi zaman açısından mümkün olmadı̆̆ i için, nitel araştırmalarda kullanılan amaçlı örnekleme yöntemlerinden ölçüt örnekleme yöntemi ile çalışmanın örneklemi belirlenmiştir. Reklam filmleri ve markalar belirli ölçütler izleğinde seçilmiş ve çalışma bu reklam filmlerinin analiziyle sınırlandırılmıştır. Ölçüt örneklem bazı özel ölçütleri karş̧layan (Tedlie ve Yu, 2007: 93) ya da belli ölçütleri sağlayan durumları belirleyen (Baltacl, 2018: 246) bir yöntem olmakla birlikte araştırma problemine ilişkin kişi, nesne ve olaylar örüntüsünden meydana gelmektedir (Nas, 2015: 18). Çalışmanın örneklemi bu yöntemle, Karatekin'in (2009: 50) sosyal sınıfın belirlenmesinde objektif (nesnel) ölçütler olarak ifade ettiği parametreler doğrultusunda seçilmiştir. Reklam filmlerinde meslek, eğitim, gelir seviyesi, gelirin kaynağı, yaşanılan ev tipi, yaşanılan çevrenin yapısı (ikametgah) ve sahip olunan mal-mülklerden (ev, yazlık, elektronik eşya, otomobil) oluşan ölçütleri söylem düzeyinde temsil eden yapılarla kurgulanmış reklam filmlerinden üçü çalışmanın örneklemi olarak belirlenmiştir.

\section{Reklamın 'Toplumsal Sınıf' Aracı Olarak Analizi}

\section{1. "Tavrın, hayat tarzın."- Renault Megane Reklamı \\ A) Reklamın Makro Yapıları}

1. Senaryo: Kırk beş saniyeden oluşan reklam filmi; öyküleme tiplerinden tüketim durumu, ürün kabulü ve tüketim etkisini ifade eden tüketici hikayesi türüne (Kawamura, 2016: 93) göre kurgulanmıştır. Film, genç yetişkin bir erkeğin iki eliyle tutarak okuduğu 'Top Management' dergisinin ön ve arka kapağının görüntüsüyle başlamaktadır. Karakter, dergiyi kapatıp alaycı bir şekilde gülümser. Bu sırada karakterin sadece eli görüntülenir ve o sırada kendisi, aracının anahtarını alır. Bir sonraki sahneden karakterin evden çıktığı ve otomobiline doğru yürüdüğü görüntülenir. Daha sonra bagajın bulunduğu yerde karakterin sol ayağını hafif̧ce kaldırması üzerine bagajın açıldığı gösterilir. Bagajın içine yerleştirilen kamera, karakterin evrak çantasını bagaja koyuşunu görüntüler. Otomobilin sürücü 
koltuğunda oturan karakter, aracın 'open/stop' düğmesine basmaktadır. Hemen sonrasında aracın mod düğmesine bastığı görüntülenir. «Sport/comfort/eco/ neutral/perso' modlarının yer aldığı ekran açılır ve 'comfort' modunun altı kırmızı renkle çizildiği gösterilir. Araç ilerken birkaç saniye içinde arka fonda çok katlı binaların bir kısmı gösterilmektedir. Daha sonra yine otomobilin içinden karakterin mesaj kutusuna baktığını görürüz. Okunmamış mesajlar içinden 'Berkalp Diner'in 15:39'da attığı 'Re: Öğle Yemeği' mesajını açar ve Berkalp'in «Öğle yemeğine ne dersin?» mesajını sesli bir şekilde kendisinden duyarız. Varış izlenimi yaratacak bir biçimde bir sonraki sahnede aracın bize doğru geldiği gösterilir ve hemen ardından yarısı gösterilen araç, güvenlik görevlisinin ve iş kıyafetleri giymiş kadın-erkek beş kişinin ve camekanlı bir binanın döner kapısının görüntülendiği mevkide durur. Karakter anahtarı atarken görüntülenir ve hemen ardından güvenlik görevlisinin anahtarı yakaladığını görürüz. Karakter binanın içine girer ve ilerler. Dolu asansörün açık kapısından içeri giren karakter, asansörün otuzuncu kat butonuna basmaktadır. Asansörün kapısının açılması sahnesinde karakterin tek başına o katta indiğine şahit oluruz. Ardından 'CEO' yazan kapıya doğru ilerlemektedir. Bir sonraki sahnede 'CEO' yazılı odanın kapısının açıldığı ve içeriden takım elbiseli yaşlı bir erkeğin kapıyı açtığı ve çıkmak üzere olduğu gösterilir. Karakterimiz hafif selam vererek 'patron' diyerek ilerler ve ikinci karakter şaşkınlıkla onun arkasından bakar. Daha sonra ofis olduğu anlaşılan mekâna giren ana karakterin sandalyesini çekerek çalışma masasına oturduğunu görürüz. Tam bu sırada karşısındaki kıvırcık saçlı üçüncü bir karaktere 'günaydın' der. Bunun ardından kamera ofis ortamını gösterir. Son olarak kamera tekrar otomobilin yolda ilerleyişini gösterirken dış ses görüntünün sağ köșesine iliştirilmiş “Yeni Renault Megane Sedan Tavrın, Hayat Tarzın.” yazını seslendirir. Son olarak otomobilin logosu ve ana sloganını (Passion for life) içeren pack shot girer.

2. Slogan: Slogan, belirli bir reklam kampanyası sırasında bir ürün ya da hizmetin akılda kalıcı olması için tasarlanmış bir ifade (Goddard, 1998: 125) olarak tanımlanmaktadır. Tüketicinin markayı hatırlama, markayla ilişkilendiren ifadeleri ve anlamları özdeşleştirme, markayı algılama biçimini yönetme açısından önem taşımaktadır. Aynı zamanda markanın temel vaadi de sloganın yapı taşlarından biridir. Bu bağlamda Renault markasının bu reklam filminde belirli bir yaşam (hayat) tarzı vaadinde bulunduğu görülmektedir. Yaşam tarzı, Weberci terminolojiyle 'toplumsal statü gruplarının' gündelik hayatlarında ve yaşamlarının bütününde belirli ortaklıklarını yansıtan toplumsal sınıflandırmada ayırt edici bir parametredir. Featherstone'un (2013: 149) altını çizdiği gibi bireyin "bedeni, giysileri, konuşması, boş zamanı kullanması, yiyecek içecek tercihleri, ev otomobil ve tatil seçimleri gibi" kültürel nesne aidiyetleri ya da Bourdieucu bir ifadeyle beğenileri bireyin yaşam tarzının işaretlerdir. Bu anlamda 'Tavrın, hayat tarzın' sloganıyla Renault, sunduğu ürünle tüketiciye bir yaşam tarzı vaat etmektedir. 'Tavır' kelimesiyle belirli bir davranış biçimine atıfta bulunan marka, tüketicinin tavrının yaşam tarzı göstergesi olduğunu ima etmiştir. Rasyonel fayda yerine tamamen sembolik faydaya-"tüketimin kimlik oluşturma boyutu"na (Odabaşı, 2013: 18)- yönelen markanın sloganı, Baudrillard'ın (2013: 93) Mercedes-Benz reklamı incelemesinde ortaya koyduğu gibi tüketicinin kimliğini farklılaștırma amacını taşımaktadır. Çünkü tavırların hayat tarzı olduğu bir toplumsal sistemde birini A kişisi yapan semboller, diğerini B kişisi olarak kodlarken aynı zamanda B kişisini A kişisi olmayan olarak işaretlemektedir. Dolayısıyla Renault'un reklam filminin sloganı, toplumsal bir hiyerarşiyi tesis etmenin aracı olarak dolaylı yoldan kendisini imlemektedir. 
3. Mekân: Reklam filminde iç mekân ve dış mekânın ikisi de yer almaktadır. Ancak iç mekân olarak önce ana karakterin evi daha sonra çalıștığı işyerinin (plaza) içerden girişi, koridorları, asansörü, ofis kısmı ve otomobilin içi kullanılmıştır. Dış mekân olarak ise evin bahçesi ve çevresi, yol, köprü ve iş yerinin dışarıdan girişi seçilmiştir. Öncelikle ana karakterin yaşadığı ev, bahçe düzenlemesi, çalıştığı plaza, otomobil yolda ilerlerken gördügümüz camekanlı binalar (gökdelen) ve asansörde otuzuncu kata basması bütünüyle yeni küçük burjuvazinin değerlerini yansıtmaktadır. Modern bir şekilde dizayn ve inşa edilmiş, salonunda yere kadar uzanan camları bulunan, bahçesinde havuzu olan ve dinlenmek için oturma mobilyası yer alan evin gri, simetrik, köşeli ve düz yapısı ana karakterin maddi gücünü temsil etmektedir. Ayrıca rekabet, steril hayatlar ve kapalı alanların örgütlenmiş biçimi olarak plazalar ile gökdelenler alışkanlık ve sabitlenme arasındaki gerilimle mücadelenin merkezleri olarak yeni küçük burjuva yaşamının yaygınlaşan hırs mekanlarıdır. Daha hızlı olma, yükselme ve güçlü olma niteliklerinin rekabetçi unsurlarıdır (Ergur, 2012: 16, 41). Karakterin kendi eviyle ilgili tercihleri/beğenileri ve günlük yaşamının akışında karşılaștığı ya da ait olduğu mekanlar açısından, Bourdieu'nun sermaye tipleri bağlamında, sınıfsal bir üstünlük yarışı belirginleștirmektedir.

4. Karakterler: Reklam filminde ana karakter, sadece sesini duyduğumuz ve textmesaj gönderdiğini bildiğimiz Berkalp Diner, plazanın güvenlik görevlisi, danışmada bulunan iki adet genç kadın, asansörde biri kadın olmak üzere beş kişi, iş yerinin/ ofisin Ceosu ve ana karakterin çalışma masasını paylaştığı iş arkadaşı yer almaktadır. Tüm reklam filmi boyunca karakterler takım elbiseli görüntülenmektedir. Takım elbise, 19. yüzyılın sonlarında İngiltere'de ortaya çıkmış bir kıyafet türüdür. Üst sınıf erkeklerinin iş gücü piyasasına girmek ve hayatlarını devam ettirmek için çalışmak zorunda kaldıkları bir dönemin giysisidir. Hızlıca beyaz işçiler arasında yaygınlaşarak, dünya çapında ofis giysisi olarak standartlaşmıştır ve o zamandan beri iş yerlerinin mutlak kıyafeti olmuştur (Särngren, 2006: 15). Bu bağlamda ofis yaşamı ve takım elbise arasında standardizasyon ilişkisi bulunmaktadır. Hem kadın hem de erkek karakterlerin bu giyimi geleneksel anlamda işin maskülen ve rasyonel tarafına gönderme yapmaktadır. Çalışanların giyimleri benzer şekilde yaşam tarzları hakkında ipucu vermektedir. Güvenlik görevlisi üniforma giyerken, danışmada bulunan iki adet genç kadının aynı renkte ve tipteki kıyafeti onların sosyo-ekonomik düzeylerini diğer çalışanlara göre alta çekmektedir. Ancak giyim açısından bu kişilerin dıșındakilerin sınıfsal durumu benzer görünmektedir.

5. Toplumsal/Kültürel/Sınıfsal Bağlam: Fromm'un da belirttiği gibi (2002: 4950) yirminci yüzyıl ve sonrası için harcama üzerine kurulu bir kapitalizmden bahsetmek gerekir. Baudrillard (2014: 240) -Fromm'dan birkaç yıl sonra- insanın her zaman satın aldığını, sahip olduğunu, zevk aldığını ve para kazandığının altını çizmiş ancak "tüketim" bahsinin çağdaş toplum için geçerli bir kavram olduğunu vurgulamıştır. Yine Baudrillard bir önceki yüzyıl toplumlarının işinin üreterek artı ürün yaratma olduğunu fakat günümüz toplumunun toplumsal işinin tüketmek olduğunu ifade etmiştir. Günümüze daha yakın bir tarihte, 1998 yılında, Bauman, önceki yüzyll toplumları ve bugünün toplumu arasındaki farkı, öncüllerine benzer biçimde, ortaya koymuştur. Ona göre de dünün toplumunun biriktirmek, tasarruf etmek ve yatırım yapma gibi bir püriten (tutucu) anlayışının yerine günümüz toplumunda üretici yerine tüketici merkezli hedonist (hazcı) bir anlayış gelişmiş ve tüketimciliğin yayılması önem kazanmıştır (Akt: Şentürk, 2012: 68). Tüketimciliğin 
baskın olduğu özellikle günümüz postmodern toplumunda, Bourdieu'nun sinıf anlayışı göz önünde bulundurulduğunda, sembolik sermayeler olarak nesnelerin (bu durumda otomobilin) bireyin sınıfsal konumunu yansittığı söylemek mümkündür. $\mathrm{Bu}$ bağlamda reklam filmi, tüketim nesnelerinin sınıfsal konuma eklemlenmesinin izlerini taşımaktadır. Reklam filminde kullanılan 'Top Management Magazine" isimli iş derginin kapağında yer alan "CEO OF THE YEAR (Yılın CEO'su)" ifadesindeki Ceo kavramının İngilizce açlımı "chief executive officer" olup baş icra sorumlusu, baş yönetici, icra kurulu başkanı ve genel müdür gibi bir şirketin yönetiminin en üst kademesindeki sorumlu kiși anlamına gelmektedir. Reklam filmi boyunca, karakterin otomobil aracılığıla kendini "CEO" gibi hissetmesi teması göz önünde bulundurulduğunda, sinıfsal bir konum edinmede Renault'un ürününün toplumsal sınıf özelinde işlevsel bir anlam taşıdığı anlaşılmaktadır. Bu doğrultuda "Yeni Renault Megane Sedan" tüketiciye sinıfsal bir konum vaat etmektedir. Sosyo-Ekonomik Statü (SES) grupları düşünüldügüunde eğitim seviyesi oldukça iyi nitelikli uzman (Eyüboğlu, 2012) grubuna dahil olan CEO mesleği, profesyonel bir iş yaşamını çağrıştırmaktadır. Kotler'in (2002: 90) toplumsal sınıfları düşünüldüğünde tamamen kendi imkanlarıyla, aile ya da sürpriz bir zenginlik sahibi olmayan ve profesyonel olarak kendi kariyerlerine odaklanan bağımsız iş adamları, şirket yöneticileri ya da kurumsal yöneticileri içeren üst orta sınıfı (upper middles) geniş anlamda ise geleneksel küçük burjuvazinin post modern görünümünü hedeflemektedir. Nitekim araç içindeyken karakterin (17. sn), gelen kutusunda tamamen iş hayatıyla ilgili mesajların bulunması da bu sosyal sinıf durumunu desteklemektedir. Bununla birlikte araca binen karakterin, ilk anda (12. sn) mod seçiminde 'konfor' seçeneğine tıklaması da aynı şekilde sınıfsal mevkiine gönderme yapmaktadır. Çünkü otomobilin tüketiciyle konuşan bölümü/iletişim kuran kısmı motor ya da aksamları değil, "biçimi, rengi, hatları, aksesuarları" daha genel anlamda konfor düzeyinin simgeleridir (Baudrillard, 2014: 230). Konfor; bireyin başkalarından ayrılma/ başkalarına benzememe arzusunun, ekonomik ve sosyal sermayesinin, sahip olduğu olanaklarının ve para harcayama kapasitesinin bir göstergesidir. Aynı şekilde karakterin iş yerine ulaştığında güvenlik görevlisine otomobilin anahtarını atarak güvenlik görevlisini vale yerine koyması yine tüm bu üst sınıf konumlandırmasını pekiştirmektedir. Vale, hizmet sektörünün gelişimin bir işareti olmakla birlikte lüks tüketim ve Veblen'in (2014) gösterişçi tüketim mantığıyla bir alt sınıf pratiğidir. Modern köleliğin bir biçimi olarak Vale, küçümsenen 'ayak işlerini' yerine getiren ve hizmet eden kişidir. Böylece reklam filmi, iki sınıf arasındaki ayrımı hizmet eden ve edilen bağlamında net olarak çizmektedir.

\section{B) Reklamın Mikro Yapıları}

1. Cümle Yapıları ve Sözcük Seçimleri: Eldeki derginin kapağındaki yazı, ana karaktere gelen mesaj, ana karakterin hem amirine hem de çalışma arkadaşına verdiği selam ve markanın bu kampanyaya özgü sloganı ile pack shotta yer alan ana sloganı reklamın cümle ve kelimelerini oluşturmaktadır. İlk olarak, derginin kapağında bulunan 'Yılın CEO'su' ifadesi dilbilimsel açıdan bir derecelendirmeyi içermektedir. Yıl içerisindeki rekabeti betimleyen bu ifade, reklamın üst orta sinıf beyaz yakalı çalışan temasına uygun olarak CEO kelimesini öne çıkarmaktadır. İkincisi ana karakterin kendi üstüne selam vermek için 'patron' kelimesini kullanması sözcük seçimi açısından yine reklamın temasındaki otomobilin bir üst yaşam tarzına geçişte önemli olduğu vurgusunu desteklemektedir. Bununla birlikte iş arkadaşına klasik 'günaydın' selamını vermesiyle ana karakterin toplumsal hiyerarşiyi dile 
aktarmasını örneklendirmektedir. Bunlara ilaveten 'Tavrın, hayat tarzın." sloganının düzenli, imla kurallarını dikkate alan ve sözcüklerin kafiye boyutuyla düzenlenmiş bir cümle olduğunu görülmektedir. İş yaşamının formel ve ciddiliğinin bu dizilișe de yansıdı̆̆ı söylenebilir.

2. Çekim Tipi: Reklam filminde yakın plan, gögüs plan, omuz plan, genel plan, boy plan, bel plan, çok yakın plan ve ayrıntı plan kullanılmıştır. Bir reklam için önemli olan ürünün özelliklerinin ve vaatlerinin daha net algllanması olduğu fikri göz önünde tutulursa, bu reklamda özellikle arabanın spesifik teknik becerileri yakın planlar ve ayrıntılı planlarla çekilmiştir. Örneğin otomobilde mod seçimi, ana karakterin otomobil anahtarını alması ve bagajın içi bu şekilde görüntülenmektedir. Fakat otomobilin genel görümünü için genel plan tercih edilmiştir. Öte yandan reklamın yaşam tarzı temasına uygun olarak karakterin tüm yaşam tarzının nesneleri ve mekanlarını göstermek için genel planlar uygulanmıştır. Örneğin ana karakterin evinin ve bahçesinin bir kısmı, plaza ve çalıştığı ofis genel planla çekilmiştir.

3. Müzik/Jingle- Ses- Ses Efektleri: Kongos grubunun "Come with me now" parçası reklam boyunca çalmaktadır. Ana karakter asansöre gelinceye kadar (25. sn) parça, sözlü bir şekilde daha sonra ise enstrümantal olarak devam etmektedir. Şarkının sözleri şu şekildedir: “Ooo come with me now, Come with me now, Walk, come with me now, I'm gonna take you down, Walk, come with me now, I'm gonna show you how" (Şimdi gel benimle, şimdi gel benimle, şimdi yürü benimle, seni götüreceğim, şimdi yürü benimle, nasıl yapılacağını göstereceğim.). Şarkının sözleri tamamen antropomorfik olarak otomobilin ana karaktere seslendiğini ve otomobilin kişileştirildiğini göstermektedir. Otomobil ana karaktere çağrıda bulunmakta ve onu eğiteceğinin (bu durumda hem yaşam tarzı anlamında hem de otomobilin teknik kolaylığı bakımından) mesajını vermektedir. Müzik macera, hareket, dinamizm ve eğlence hissi yaratmaktadır. Bununla beraber reklam filminde kullanılan az ve tek taraflı diyaloglardaki ses tonu iş yaşamı ciddiyetini aktarmaktadır. Ayrıca arabanın kapı açma-kapama ve bagaj kapama seslerinde efektlerden yararlanılmış, tüketicinin bu sesleri duyması sağlanmıştır.

\section{2. "Herkes Bu Prestije Sahip OImak İster."- Jetta Reklamı A) Reklamın Makro Yapıları}

1. Senaryo: Elli üç saniyelik reklam filminde takım elbiseli, elinde evrak çantası ve pardösüsü bulunan yetişkin bir erkek, havaalanının dış hatlar gelen yolcu çıkışından çıkmak üzereyken karşıdan geniş açıyla görüntülenmektedir. Karakter karşıya doğru bakmaktadır. Tam bu sırada ekrana gelen yolcuları karşılamak üzere otomobil (Volkswagen marka) önünde elinde isim yazılı (Hiroshi Nakamura) pankart bulunan Japon bir kişi boy çekimle geniş bir açıdan görünmektedir. Karakterin kamera hareketlerine göre önce ona daha sonra sadece üst tarafı görünen, bel çekimle görüntülenen, bir başka gelen yolcu bekleyen ve elindeki pankarta isim (Fernando Martinez) yazılı kişiye bakıp hızlıca aynı açıdan görünen o otomobile göz gezdirmiștir. Tekrar Japon karaktere bakan ana karakterimiz, arabayı süzüp bir iki saniye düşündükten sonra Japon karakterle göz göze gelerek ona yönelir. Yaklaştığında Japonların geleneksel selamını vererek pankartta yazılı ismi söyleyerek otomobile yönelmek üzeredir. Bu sırada Japon, işaret parmağını ana karaktere yönelterek ismi tekrar eder. Bunun üzerine ana karakter Japon'un söylediği ismin telaffuzunu düzeltmek için ismi tekrar vurgulayarak söyler. Japon bu kez beden 
diliyle (gözleri göstererek) ve sesli bir şekilde beklediği kişinin Japon olduğunu ifade eder. Ana karakter kendisinin gülümseyerek kendisinin Tokyo'lu bir Japon olduğunu ve ardından birkaç Japonca kelime ya da cümle söyler. Bunun üstünde Japon karakter "Sen Japon değilsin" der. Ana karakter bir şey söyleyerek Japon karaktere hafif sarılır, otomobilin arka kapısını açar ve içeri girer. 0 sırada diğer gelen yolcu bekleyen kişi onlara doğru bakar. Japon şaşkındır, otomobilin camına vurarak ana karaktere ulaşmaya çalışır fakat ana karakter arabanın içini gözlemlemektedir. Tam o anda diş ses "Herkes bu prestije sahip olmak ister." der. Ekranda üç dört saniye boyunca otomobilin önce ön üst taraftan sonra arka üst taraftan yolda ve köprüde ilerlediği görüntülenir. Hemen ardından tekrar karakterlere dönen kamerada ilk Japon karakterin önüne başka beklenen yolcu olan Japon'un geldiği ve selam verdiği gösterilir. Peşinden ana karakterin otomobilin camı açık bir şekildeyken omuzlarını silktiği görüntülenir. Packshot girer ve dış ses ekranda yazılı olan "Jetta. Prestij standart” sloganını okur. Son olarak Volkswagen'ın klasik logosu görünür ve marka ismi okunur.

2. Slogan: Reklam filmlerinin en önemli parçası olarak ürün ya da hizmeti doğrudan çağrıştıran ifade olarak slogan, bu reklam filminde duygusal çekicilik vaadi üzerinden kurgulanmıştır. 'Herkes bu prestije sahip olmak ister.' ifadesini sloganını ve 〈Jetta. Prestij standart.〉 ana sloganını kullanan marka, tüm reklam filminde prestij niteliğini öne çıkarmıştır. Otomobilin ayrıcalık sunduğunu belirten prestij kelimesi tüketiciye üstünlük atamaktadır. Veblen'in (2014: 37-40) gösterişçi hedonik tüketim kavrayışında belirttiği gibi zenginliği/maddi gücü göstermek için saygınlık kazandıran ürünün ihtiyaç kategorisine dahil edilmesi onu, sosyal bir derecenin belirtisi haline getirir. Bu bağlamda, söz konusu reklamdaki otomobilin vaadi prestij/saygınlık olmakla birlikte tüketimin lükse taşınmasıyla sınıfsal bir konum edinileceğinin altı çizilmiştir. Lüks tüketim ürünleri bireye fonksiyonel faydadan çok duygusal fayda sağlamaktadır. Sloganın anlam açısından herkesin böyle bir zenginlik imini arzuladığını belirtmesi yine toplumsal sınıf yapılanmasının alt ve üst katmanlarındaki gerilimi üst kapalı bir şekilde iletmektedir. Bununla beraber reklam filminin ana sloganında kullanılan «standart〉 sözcügü hem otomobilin belirli ölçülere/yasalara göre (bu durumda prestij standartlarına göre) statik olduğunu ifade etmekte hem de yaşam standartları anlamında prestijin hâkim olduğu bir yaşam tarzıyla bağlantı kurmaktadır. Bu açıdan prestij ve standart otomobile 'sahip olmakla', o ürünün kendi lehine kazanılmasıyla sağlanacaktır. Dolayısıyla gösterișçi bir arzuyla talep edilecek olan ürün pahalılığıyla kişiye bir üst sinıftan olma niteliği ekleyecektir. Orta sınıftan olan tüketiciler bu noktada yükselme göstergesi olarak harcamalarındaki artışla (Akt: Çınar ve Çubukçu, 2009: 284) kendi sınıfsal konumlarını belirginleștirmektedir.

3. Mekân: Reklam filmi hem iç mekânda hem dış mekânda çekilmiştir. Ancak mekanlar sabittir. Dış mekân olarak havaalanının çıkışı, iç mekân olarak ise ürünün/ otomobilin içi kullanılmıştır. Havaalanı çıkışı 'dış hatlar gelen yolcu' çıkışıdır. Yurt dışından gelindiği mesajını iletmek için havaalanının bu kısmı kullanılmıştır. İş gezisinin modern toplumun rasyonelliğinin kazanımlarıyla uyumlaşmış bir öğesi olarak havaalanları uluslararası ticaretin geçiş noktalarıdır. Reklamdaki havaalanı küreselleşmenin etkisiyle iş hayatı yelpazesinin genişlemesiyle imkanların genişlediğini gösteren bir temaya sahiptir. Havaalanının önünde üst orta sınıf yöneticiyi karşılamak üzere bulunan kişiler, iş hayatının artık 
gelenekselleşen hiyerarşik örgütlenmesinin küresel çaptaki durumunu gözler önüne sermektedir. Bunun yanı sıra reklamda otomobilin iç mekânı kullanılmış fakat sürücü koltuğu yerine arka kısım kısmen gösterilmiștir. Karakterin otomobilin bu kısmını izlediği noktalarda otomobilin konforla ilişkisi ve sınıfsal bir ayrıcalık sunduğu hissettirilmiştir.

4. Karakterler: Reklam filminde dört karakter bulunmaktadır. Bunlardan ilki olan ana karakter bir önceki reklam filminde olduğu gibi beyaz yakalı çalışan bedenine sahiptir. Giyimi takım elbisesi, elinde evrak çantası ve pardösüsü ile günümüzde standart üst düzey çalışan formatındadır. Kirli sakallı, beyaz, renkli gözlü, uzun boylu ve fit bir yapıda olan karakterimiz klasik orta sınıf temsilcisidir. Lefebvre'nin sınıfsal çözümlemesine göre (2013: 282), 'B.a' tipi bir sınıftan (orta sınıf- memur, diplomat, bürokrat, uzman) kimseyi çağrıştıran karakter düzgün davranış, bir ya da birkaç diploma, bilgi erdem ve prensipler silsilesiyle donatılmış görünmesi gerekmektedir. Ancak karakter davranışlarıyla (kendisini Japon olarak tanıtması ve mimikleri) bu kalıplaşmış beyaz yakalı orta sınıf bedenini gayriciddi bir pozisyona sürüklemektedir ki marka, ürünüyle vaat ettiği prestiji/saygınlığı/tercih edilme üstünlügünnü kurmak için bu yola başvurmuştur. Yine de üst orta sınıfın 'profesyonel sınıf'a ait başarılı erkeğinin dış görünüşünü yansıtmaktadır. İkinci ve üçüncü karakter ise gelen yolcuyu pankartla bekleyen kişilerdir. Bunlar biri Avrupalı ve diğeri Japonyalı iki beyaz yetişkin gençtir. Avrupalı olanı bütünüyle görüntülemeyen kamera, Japon karakteri daha geniş bir açıdan göstermektedir. Avrupalı kişi kravatsız takım elbise giyerken Japon karakter ceketsiz bir takım elbise giymektedir. Odaklanmış bir şekilde gelen yolcu çıkışına doğru bakan karakterler ise Kotler'in sınıflandırmasına göre (2002: 90), ortalama bir ücrete sahip, trendlere takip etmek için popüler ürünleri satın alan ve para harcamayı çocuklarına yönelik konularda bilhassa önemseyen orta sınıf bireylerine benzemektedir. Bourdieu'nun sınıf atlama kavramsallaştırmasına göre bu durum, sermayelerin arttırılması için daha çok çalışma pratiğiyle ve eğitime para yatırma eylemciliğiyle ilişkilidir. Bu iki kişi, bir üst sınıftan olan ana karaktere hizmet etmektedir. Reklam filminin sonunda görülen asıl 'beklenen kişi' de ana karakterle benzer özellikler taşımaktadır.

5.Toplumsal/Kültürel/SınıfsalBağlam:Toplumsal sınıflarınbedendevedolayısıyla yaşam tarzında sergilenmesi tüketim toplumunun ayırt edici özelliklerindendir. Tüketim sistemi bu anlamda üretici bir ișleve sahiptir. De Certeau'ya göre (1990: 45) kurnaz, dağınık, her yere sızan, sessiz, görünmez ve kendini belli etmeyen bu üretim biçimi egemen ideolojinin yeniden üretimine neden olmaktadır. Bu sebeple, sınıf ideolojileri, üstü kapalı bir şekilde, kendiliğinden yeniden üretilmektedir ve bu tüketimin üretimle örtüşmesidir. İncelenen reklam filminde, üst orta sınıfın nesneleri ve yaşam tarzı hakkında ipuçları verilmiş ve tüketiciye üst orta sınıf olmanın gerekli parçaları teslim edilmiştir. Markanın otomobili bu ayrıcalıklı sınıfa erişmek için araçsallaştırılan bir nesne olmakla birlikte aynı zamanda araç sahipliğinin de o sınıftan biri olmayı sağlayacağı düşüncesine eklenmiștir. "Kendisini yetiștiren ve profesyonelleşen genç, bakımlı, beyaz, yetişkin ve iyi giyimli erkek kendi sınıfsal konumuna uygun bir otomobile binmelidir." mesajı verilmiștir. Belirli bir sinıftan insanların belli tarz otomobilleri tüketmesi üzerine diğerleri onlar gibi olmayı isteyebileceklerdir ve tüketim ancak bu yolla öğrenilmektedir (Bocock: 1997: 61). Bunun yanında ana karakterin daha alt sınıftan bir otomobille beklenmesi karşısında Japon uzmanın birinci bir sınıf otomobille alınmaya gelinmesi, Japonların teknolojik uzmanlık noktasında kültürel ilerleyişini de vurgulamaktadır. 


\section{B) Reklamın Mikro Yapıları}

1. Cümle Yapıları ve Sözcük Seçimleri: Reklam filminde ana karakter ve yardımcı Japon karakterlerin diyalogları, dış ses tarafından seslendirilen sloganlar ve pankarttaki isimler vardır. Diyaloglar gündelik dile işaret etmekte, etnik kökeni Japon olamayacak Avrupalı bir yetişkinin kendini Japon olarak tanıtmak için Japonca konuşması ve beklenen kișinin ismini söyleyip telaffuzu düzeltmesi kültürel izler sunmaktadır. Slogan kurallı ve olumlu bir cümleden oluşmaktadır. Belgisiz zamirlerden 'herkes' kelimesi kullanılmıştır. 'Herkes' bu reklam filminde kolektif olarak tüm bireyleri kapsamaktadır. 'Bu' işaret sıfatıyla nitelenen 'prestij' kelimesi hem otomobili hem de saygınlığ ifade etmektedir. 'Sahip olmak' fiili ile biten slogan özel mülk edinme ve bir nitelik kazanmak anlamında iki vurguyu içinde barındırmaktadır. Yanı sıra ana karakterin havaalanı önünde bekleyen kişiyi kendisinin Japon üst yönetici olduğuna ikna etmek için iki kez ifade ismini tekrarladığı görülmekte ve telaffuz pekiștirmesi yapılmaktadır.

2. Çekim Tipi: Reklam filminde yakın plan, göğüs plan, omuz plan, genel plan, boy plan, bel plan, çok yakın plan ve ayrıntı plan kullanılmıştır. Marka, kendi otomobilini geniş planla çekip tümüyle gösterirken diğer otomobili yakın plandan fakat çok az saniyede göstermektedir. Normal şartlarda yakın plan odaklanmak için kullanılırken burada görüntünün varla yok arasında olmasına sebep olmuştur. Reklam filminin teması oyuncul öğeler barındırdığı için ana karakterin 'aldatıcı' davranışlarını 'sevimli' kılmak, muzipliği mimiklerde göstermek için kamera omuz çekime kaymıştır. Bununla birlikte otomobilin içi konformizmi belirginleştirmek için içerden ana karakteri de görüntüleyecek şekilde orta planla çekilmiştir.

3. Müzik/Jingle- Ses-Ses Efektleri: Reklam filminde Cake'in 'Love you madly" parçası kullanılmıştır. Reklam filmi boyunca vokal yerine parçanın müzikal bölümleri öne çıkartılmış, reklamın sloganı söylendikten sonra ise sözlü bölüme geçilmiştir. Sözler şu şekildedir: I don't want to fake it, I just want to make it, The ornaments look pretty, But they're pulling down the branches , Of the Tree, I don't want to think about it, I don't want to talk about it (Sahte olmasını istemiyorum, Sadece yapmak istiyorum, Süsler şirin gözüküyor, Ama ağacın dallarını aşağı çekiyorlar, Bunu düşünmek istemiyorum, Bunun hakkında konuşmak istemiyorum). Postmodern dönemin bilindik şimdiıyi yaşayan/şimdiyi isteyen toplumunun şarkı sözü olmuş halini ifade eden bu parça, Jameson'ın (2008: 13) şimdiki zamanın büyülü yapısından etkilenen tüketimci bireyin patalojikliğini göz önüne sermektedir. Diğer taraftan reklam kamusal bir alanda çekildiği için etrafın sesleri diyaloglara karışmaktadır. Ortamın canlılığı ile doğallığı mizansenin normalleştirilmesine hizmet etmektedir. Karakterlerin ve dış sesin de ses tonlarından ise 'sevimli' ve 'güleğen' öğeler sezilmektedir.

\section{3. "1. Sınıf Tercih"- Opel Insignia Reklamı}

\section{A) Reklamın Makro Yapıları}

1. Senaryo: Yirmi sekiz saniyelik reklam filmi, bir uçağın "business class" bölümünde sarışın genç kadın bir hostesin servis yaptığı anı görüntülemekle başlar. Hostes arkasını dönerek tam o bölümün perdelerini kapattığında yerde (ekonomik sınıfın alanında) markası (Opel) logosu da bulunan otomobilanahtarınıgörür.Elinde anahtarı gördügümüz hostes, ekonomik sınıfın yolcularına doğru "Affedersiniz, anahtarını kaybeden var mı?" der ve yolcuların başını iki yana sallayarak "hayır" işareti yaptı̆̆ı 
görülür. Hostes yolculara bakınırken arkadaki perde açılır ve yetişkin bir adam elini uzatarak "Evet" der. Hostes yüzünü o yolcuya doğru döner ve yolcu "Sanırım benim." derken hostes elindeki araba anahtarına bakıp "A, tahmin etmeliydim." der. Bunun üzerine yolcu "Her yolculukta birinci sinıftayım." cümlesini kurar. Ardından parlak güneş ışığı altında otomobil ön ve arka tarafından görüntülenir. Daha sonra uçaktaki yolcunun otomobili sürdüğünü ve kahkaha attığını görürüz. Ardından dış ses "Opel Insignia. Birinci sınıf konfor ve teknoloji için birinci tercih." cümlesini seslendirdiği sırada otomobilin muhtemelen katlı otoparkta üste kata çıkıp durduğunu ekranda görülür. Logo ve sloganın bulunduğu pack shot görünür ve o sırada dış ses marka ismini ve sloganı seslendirir. Son olarak otomobilin teknik bir özelliği ekranda belirir ve dış ses tarafından «Üstelik Insisnia1.6 Dizel Otomatik» denilerek seslendirilir.

2. Slogan: Marka konumlandırmasının ipuçlarını veren slogan yerine bu reklam filminde "Birinci sınıf konfor ve teknoloji için birinci tercih." cümlesi seçilmiştir. Sloganın anlamsal örüntüsünden anlaşılacağı üzere markanın temel vaadi, otomobili, doğrudan sınıfsal bir konum aracı olarak tanıtmasıdır. "Birinci sınıf" ifadesi hem kalite anlamında hem de yaşam tarzı ve olanaklar bağlamında tüketicinin mükemmellik, kusursuzluk ve maddi gücü temsil etmektedir.

3. Mekân: Reklam filminde iç mekân olarak uçağın business class ve economy class bölümleri ile otomobilin içi ve çok katlı otoparkın içi dış mekân olarak ise otoban kullanılmıştır. Uçak içi bölümlendirme harcama özgürlügüne ve yetkinliğine göre toplumsal sınıflandırmanın somut mekanlarıdır. Her ne kadar "business" kelimesi belirli bir mesleki icrayla ilgili görünse de bu kavram modern anlamda girișimciliği, işletmeciliği, rekabetçiliği ve hırsı içinde bulunduran çağrışımlarla doludur. Bu açıdan toplumsal sınıf noktasının bu kelimeyle ifade edilişi, mesleğin sınıfsal konum edinmede ne derece etkili olduğunu göstermektedir. Uçak yolculuğu yapılırken bireyin kendi sınıfsal konumuna göre uçak hizmetlileri tarafından muamele göreceğinin de işaretlerini vermektedir.

4. Karakterler: Reklam filminde ana karakter, hostes ve uçakyolcularıbulunmaktadır. Ana karakter beyaz, orta yaşlı, gözlüklü, sarışın ve "smart causal" giyimlidir. Temel ihtiyaç kategorisindeki giyim-kuşamın yaşam tarzını belirginleştirmesinin yanında Bourdiecu bakışla sınıfsal ayrımları netleştirdiği savunulabilir. Bu anlamda üst orta sınıf temsilcisi iş hayatında üst kademe çalışanı olan ana karakterin bedenin fiziksel durumu ve onun toplam görümü sınıfsal beğenisinin normlarını sunmaktadır. Hem ciddi hem de rahat giyimi bir arada gösteren smart casual giyim ana karakterin çalışma hayatındaki durumunu sembolize ederken aynı zamanda o çalışmanın kendisine sunduğu rahatlık/konfor fırsatını gösterileştirmektedir. Aynı şekilde yan karakterlerden hostesin klasik olarak üniformasını giyişi; iş yaşamında kendisine dayatılan zorunluluğu ve giyimle standartlaşan mesleğini ya da Althusser'in özneyi çağırma analizinde olduğu gibi hostesi üniforma ile işaretleme ve giyimle ona öznelik durumunu atama gibi anlamalara gelebilir. Buna eş olarak 'business class' bölümünde bulunan yolcuların bedenlerinin öğeleri ana karaktere benzerken, ekonomi sınıfındaki yolcular daha gündelik giyinmiş, belirli bir stereotip yerine kadın, erkek, yaşlı, genç, orta yaşlı, sarışın, esmer, kumral ve vücut tipi statik olmayan çeşitli kişilerden oluşmakta ve orta sınıfın gündelikliğini göstermektedir. Simgesel boyutta daha gündelik görünen bu yolcular sınıf konumunun pratik ifadeleridir. 
5. Toplumsal/Kültürel/Sınıfsal Bağlam: Yaşam tarzı sınıf ilişkilerinin simgesel boyutunu oluşturmaktadır. İşlevsel faydadan ziyade sembolik ve duygusal faydayı tematik olarak reklam filminde, dilbilimsel açıdan mekân isimleri üzerinden sınıfsal ayrılık tesis edilmiştir. Uçak yolculuğunda birinci sınıf yolculuk yapmayı seçen ve ihtiyaç olmayan bu durumun (işlevsel anlamda uçaktaki tek bir koltuk o yolculuğu sağlama yeterliliğine sahipken) sınıf özelinde alışkanlıktan doğan bir sınıf pratiği haline dönüşmesi Bourdieu'nun sembolik sermaye betimlemesini hatırlamaktadır. Buna göre bireyin sosyal, ekonomik ve kültürel sermayesini bir başka ifadeyle sınıfsal konumunu sembolik aidiyetleri onaylamaktadır. Bu bağlamda reklamdaki ana karakterin uçakta tercih ettiği yolculuk tipinden bütün yolculuk faaliyetlerinde birinci sınıf tercihinde bulunması onun iktisadi ve sosyal sermaye açısından toplumsal hiyerarşide üst bir basamakta olduğunu göstermektedir.

\section{B) Reklamın Mikro Yapıları}

1. Cümle Yapıları ve Sözcük Seçimleri: Reklam filminde hostesin ekonomi sınıfı yolcularına hitaben kurduğu cümle, hostes ve ana karakter arasındaki birkaç cümle ve dış sesin seslendirdiği slogan bulunmaktadır. Önce hostes, görgü kuralları dahilinde ekonomi yolcularına seslenirken c «afedersiniz" kelimesini kullanmaktadır. $\mathrm{Bu}$, mesafeli/resmi iletişiminin ve hizmet eden ve hizmet alan arasındaki sınıfsal ayrımının bir göstergesidir. Ana karakterle hostesin diyaloğunda ana karakter markanın ürünün anahtarının business class yolcusuna ait olabileceğini "tahmin etmeliyim" ifadesiyle yanıtlamaktadır. Tahmin etmek, belirli bir durum hakkında öngörüde bulunabilmek anlamına gelmektedir. Geçmiş zamanla ifade edilen bu eylem doğal ve kesine yakın bir öngörünün gerçekleștirilmemiş olmasında kendisini eleştiren hostesin dilinde somutluk kazanmaktadır. "O otomobilin anahtarı elbette o sınıfın yolucusuna ait olacaktır ve bunu düşünememek kendi eksikliğidir." "Her yolculukta birinci sınıftayım." diye cevap veren ana karakterin bu cümlesinde, reklamın temasına uygunluk olarak birinci sınıf vurgusu yapılmıștır. Bununla birlikte ilgili cümle olumlu, birinci tekil şahısla ve mecaz anlamla kurulmuş isim cümlesidir. Cümlede kullanılan 'her' ifadesi yaygınlığı, 'yolculuk' ifadesi herhangi bir taşıtla gidişgeliş süresini ve 'birinci sınıf' ifadesi ise toplumsal konumu belirtmektedir. "Opel Insignia, birinci sınıf konfor ve teknoloji için birinci tercih." sloganı geniş zamanla kurulmuş, tanım yapan bir formata sahiptir.

2. Çekim Tipi: Genel plan, bel plan, gögüs plan ve omuz plan kullanılmıştır. Genel plan çekimlerde hem otomobilin genel görünümü hem de mekânın genel özelliklerinin yansıtılması hedeflenmiştir. Bel plan çekimlerde sınıfsal ayrımın hiyerarşik boyutu ima edilmiş; alt ve üst sınıf ayrımın belirginleșmesi sağlanmıştır (uçak içinde üst orta sınıftan olan ana karakterin perdeyi açtığı sırada ekonomi yolcularına kıyasla bedeninin duruş hizasının bir üstte bulunması). Gögüs ve omuz planlarda ise otomobilin içindeki tüketicinin aldığı haz beden diliyle gösterilmek istenmiştir. Reklam filminde yakın çekim planı sadece otomobil anahtarına uygulanmış ve böylece temel aidiyet temasının anahtar figürü ön plana çıkartılmıştır.

3. Müzik/Jingle- Ses-Ses Efektleri: Reklam filminde ilk yarısında uçak içindeki ortamın sesini ve hostes ile ana karakterin diyaloğunu duyuyoruz. Diyaloğa fon olarak ortamın sesi kullanılmıştır. Ana karakter kendinden emin, hostes ise nazik bir ses tonuyla konuşmaktadır. Daha sonra otomobil içi ve dışı çekimlerde dış ses sloganı seslendirirken arkada müzik çalmaktadır. Müziğin kime ait olduğu ve hangi parça olduğu anlaşılmamakla birlikte müzik türü olarak "country" janrında bir 
müzik kullanıldığı söylenebilir. Country müzik türü, klasik Amerikan beyaz erkeğinin simgesi ve kovboyluğu sembolik düzlemde ifade eder. Her ne kadar kovboyluğun ortaya çıkışı sınıfsal açıdan çobanlıkla eş anlamlı olsa da modern anlamda kovboy maceracı, korkusuz, cesur, kendine güvenen bir kişiyi temsil etmektedir.

\section{Sonuç}

Toplumsal yaşamda bireylerin sosyo-ekonomik düzeylerine göre sınıflandırılmasının iktisadi ve sosyolojik bağlamda görünür olduğunu tartışan birçok teorisyen, bugüne dek bizlere birikmiş bir literatür sunmuştur. Onlardan ilk sıraya yerleşen ve toplumsal sınıf kavramıyla toplumsal hayatın ekonomik temellerine bağımlı bir kültür teorisi ortaya koyan Marx, bireyler arasındaki hiyerarşik yapılanmayı ideolojik bir yanılsama olarak yorumlamıştır. Ona göre yöneten ve yönetilen arasındaki tüm ilişkiler maddi aidiyetlerin sonucudur ve kültür de bu aidiyetlerden türemektedir. Bu doğrultuda modern kapitalist toplum işçi sınıfı, burjuva sınıfı ve küçük burjuvazi olarak üç gruba ayrılmaktadır. Burjuva sınıfı yönetici sınıf olarak, işçi sınıfı yönetenlere emeğini satarak hayata tutunmaya çalışan bir sınıf olarak ve küçük burjuvazi ise işçi sınıf ile burjuva sınıfı arasındaki bir yerde bir nevi arabuluculuk eden ve iki sınıfın özelliklerini de gösteren bir şekilde tasvir edilmektedir. Ancak toplumsal sınıfların ekonomik determinizm ölçeğinde analiz edildiği ve kategorilendirildiği bu açıklama Weber tarafından kültürü öne çıkartacak bir biçimde yeniden yorumlanmıştır. Weber, toplumsal sınıfların bu kadar keskin bir şekilde ekonomik düzeyle ilişkili olarak bölünmediğini ve kültürel farklılıklardan kaynaklı bir toplumsal sınıf durumunun daha gerçeğe uygun olduğunu düşünmüştür. Sosyal statü kavramını oluşturarak sınıflar arası farklılıkları yaşam tarzı, eğitim ve tüketim kalıpları gibi pratikler aracılığıyla açıklamıştır. Onun ardından Batı Marksistleri de benzer şekilde ekonomi temelli bir sınıf anlayışı reddederek egemen ideolojinin kültür inşasına odaklanmıştır. Marx'ın meta endeksli anlatısını daha geniş bir alana taşıyan Lukacs, toplumsal hayatta tüm ilişki biçimlerinin üst çatısı olan kültürün de meta mübadelesinin bir yansıması olarak gerçekleştiğini (şeyleşme) savunmuştur. Gramsci toplumsal sınıfların yeniden üretiminde hegemonik kurumlar ve araçlara değinmiş, Ortodoks Marksizm'inin klasik "alt yapı üst yapıyı belirler" savını eleştirerek üst yapının (kültür) görece özerkliğini ileri sürmüștür. Althusser ise psikanalitik kuramına yaslanarak, toplumsal sınıfların yeniden üretiminin, kültürel aygıtların bireyleri birer özne olarak 'çağırması' ile medyada geldiğini ifade etmiştir. Literatür tam da bu devreye ulaştığında artık toplumsal sınıfların ideolojik üretiminde dilin önemli bir araç olduğu ortaya çıkmıştır. Foucault dili egemen söylemin bir aracı olarak kodlamıș ve tarihsel öznenin aslında kendi kendini nesneleştirdiğini savunmuștur. Bourdieu toplumsal sınıf meselesini çok daha geniş bir çerçeveye oturtarak sadece dilin değil aynı zamanda bedenin de toplumsal sınıf işaretlerini taşıdığını ve onun yeniden üretiminde belirgin bir rol aldığını aktarmıştır. Bourdieu'un toplumsal sınıfları sadece ekonomik sermayeyi değil aynı zamanda kültürel, sosyal ve sembolik sermayeleri de bir bedenlerinde taşıyan bireylerden oluşmaktadır.

Tüm bunlardan hareketle reklamlar filmlerine yoğunlaşan bu çalışma, "Reklam metinleri, nesneleri toplumsal sinıf atlama aracı olarak hangi görsel ve dilsel unsurlarla birlikte ideolojik bir söylem içerisinde inşa eder?" sorusundan yola çıkmıştır. Reklamlar, toplumsal örgütlenmenin ve hiyerarşinin inşasında, yapılandırılmasında ve temsili noktasında önemli görevler üstlenmektedir. Her șeyin 
reklam biçimini aldığı günümüzde, insan bedenleri de kimliğin farklılaştırıcı öğelerini içermekte ve yansıtmaktadır. Bu açıdan reklamlarda kullanılan insan bedenleri, o karakterlerin yaşam biçimlerinin temel özellikleri, reklamda kullanılan mekândan ses tonuna kadar birçok unsur, sembolik anlamda, bireyin toplumsal sınıf skalasında nerede yer aldığını göstermektedir. Çalışmada televizyonda yayınlanan reklamların ideolojik bir söylem pratiği içerisinde nasıl kurgulandığını incelemek adına van Dijk'ın haber söylemi için geliştirdiği eleștirel söylem analizi reklam metinlerini analiz etmek için uyarlanmıştır. van Dijk'ın haber söyleminin bileșenlerini makro ve mikro yapılar olarak parçalara ayırmasını baz alarak reklam bileșenleri makro ve mikro yapılar olarak ele alınmıştır. Bir reklam filminin tüm bileşenlerinin analizi bu bağlamda birbirini içereceği ve çalışmayı tekrara sürükleyeceği için reklam filminin geniş ölçekli bileşenleri analiz edilmiş ve bu analizler içerisinde diğer bileşenlere yer yer değinilmiştir. Bununla birlikte çalışmanın evreni Lefebvre'nin otomobil nesnesine hem gündelik hayatı düzenleme hem de toplumsal sınıfı/tabakalaşmayı organize etme görevi addettiği çalışmasından yola çıkarak oluşturulmuş ve otomobil sektörü reklamları evren olarak belirlenmiştir. Ancak çalışmanın zaman problemi göz önünde bulundurulduğunda yayınlanmış reklamların tümünün analizinin mümkün olmadığı hesaba katılarak ölçüt örnekleme yöntemiyle kişi, nesne ve olay örüntüsünde toplumsal sınıfın izlerinin aranmasını sağlayacak ölçütler aracılığıyla sınırlandırılmaya gidilmiş ve ulaşılan reklam filmlerinden üçü çalışmanın örneklemi olarak belirlenmiştir. Bunlar; Renault, Jetta ve Opel'in toplumsal sınıf temalı birer reklam filmidir. Her reklam filminin makro yapısında senaryo, slogan, mekân, karakterler ve toplumsal bağlam; mikro yapıda ise cümle yapıları-sözcük seçimleri, çekim tipi, müzik, ses-ses efektleri ile analiz edilmiştir.

Üç reklam filminin makro yapılarının çözümlemesinde, senaryoların ana söyleminin toplumsal sınıf sembolleri üzerine kurulduğu saptanmıştır. Aynı şekilde analiz edilen her bir reklam filmi, bireyin kendi toplumsal sınıfından bir adım üsttekine (üst-orta sınıf) sıçraması, otomobil nesnenin sunduğu olanaklara bağlanmaktadır. Reklam filmlerinin ana karakterleri otomobille edinecekleri toplumsal statüye 〈özenen〉 ve onu arzulayan davranışlar sergilemektedir. Reklam filmlerinin sloganları da benzer şekilde sınıfsal konumun aracı olarak otomobili işaret etmiş; standartların, ayrıcalığın, prestijin, saygınlığın ve yönetici sınıfta yer almanın söylem alanında sembolik nesnesini otomobil olarak belirlemiștir. Otomobil böylece bir fetiş nesnesi olarak büyülenmiștir. Benzer şekilde reklam filmlerinde kullanılan mekanların dili de hırs, hız, yükseklik, rekabet ve özel gibi Foucault'cu bir ifadeyle bölücü söylemler üzerinden yaratılmıştır. Üstelik mekânın dizaynı ve bir bütün olarak parçalara ayrılışı da bireylerin belirli toplumsal sinıflara aidiyetleri sebebiyle ancak mekanların belirli yerlerinde konumlanabileceğini göstermektedir. Bununla birlikte reklam filmlerinde yer alan ana ve yan karakterlerin kostümlerinden bedenlerinin görünüşlerine ve davranışlarına kadar sınıfsal ipuçlarıyla donatıldığı tespit edilmiştir. Toplumsal tabakalaşmanın yaygın işaretlerini taşıyan bu sınıflı bedenler için otomobil hem sembolik hem de kültürel sermayenin söylevini içermektedir. Analiz edilen reklam filmlerinin sınıfsal bağlamına bakıldığında ise kendini CEO hissetme, yönetici bir sinıf mensubu olma ve birinci sınıf birey olmanın ideolojisi otomobil ve onun tasarımına aktarılmıştır. Bireyler artık Weber ve Bourdieu'nun toplumsal sınıf anlayıșı ekseninde söylenecek olursa, neyi nasıl tükettikleriyle belirli bir sınıfın mensubu olarak kabul edilmektedir ve söz konusu reklam filmlerinin söylemi de bu doğrultuda inşa edilmiştir. Mikro yapılarında ise ilgili reklam filmlerinin 
cümle yapıları, kelime seçimleri, müzikte kullanılan ifadelerde ve kullanılan çekim tipinde bireyler arasındaki hiyerarşiyi/toplumsal bölünmeyi ifade edecek yapısal örgütlenmeler bulunmaktadır. Aynı șekilde kullanılan ses ya da ses efektlerinin macera, hareket, dinamizm ve eğlence gibi öğeleri ön plana çıkardığı görülmektedir. Ayrıca diyalog ve monologlarda dahi kullanılan ses tonlarının sınıfsal hiyerarşiyi yansıttığı sonucuna ulaşılmıştır.

Sonuç olarak, bu çalışma boyunca toplumsal sınıfın, reklam filmlerinde söylem düzeyinde nasıl yapılandırıldığına odaklanılmıștır. Çalışmanın örneklemini oluşturan reklam metinlerinin, toplumsal sınıfı yapısal bağlamda inşa ettiğine ulaşılmıştır. Yazarların van Dijk'in eleştirel söylem analizini reklam metnine uyarlama çabası, elbette deneysel bir aksiyondur. Ancak söz konusu uyarlamanın geliştirilerek evreni daha çok kapsayacak bir örneklem yöntemiyle ve reklam metinlerinin diğer bileșenlerinin de yer aldığı bir şablon dökümüyle yapılacak bir araştırma, ideolojik bir nesne olan reklamın işleyişi hakkında daha çok ipucu verecektir.

\section{Notlar}

${ }^{1}$ Althusser'i izleyen Poulantzas, sınıf analizinde üretim ilişkilerinin geleneksel Marksist anlayışındaki öncül olma durumunu ertelemiş ve sınıfların oluşumunu "toplumsal formasyonların tümünün yarattığı etkiye" bağlamıştır. Sınıfsal bölünme onun için homojen olmaktan ziyade farklı toplumsal öznelerin bulunabileceği heterojenliği içermektedir. Poulantzas bu doğrultuda küçük burjuva sınııını geleneksel burjuva sınıfı (esnaf, küçük tüccarlar gibi) ve 'üretken olmayan ücretli işçilerden' ve memurlardan oluşan yeni küçük burjuva sınıfı olarak ikiye ayııır. 0 yüzden ekonomik ölçütün yanı sıra politik ve özellikle ideolojik ölçütün de bir öznenin sınıfsal konumunun tespitinde işlevsel olduğunun altını çizmektedir (Koşar, 2017). Wright ise burjuva sınıfındaki çelişkili durumları işaretleyen orta sınıf/küçük burjuvazi analizlerini genişletmiştir. Ona göre geleneksel burjuva işçi sınıfı şablonlarında çelişkili mevkilerde bulunanlar sınıf sistematiğinde önemli grupları oluşturmaktadır. Bu sebeple onlu bir sınıf kategorilendirmesi yapmıştır. Bu durumda burjuvazi (geleneksel kapitalist), çelişkili mevki (üst düzey şirket yöneticisi), çelişkili mevki (üst düzey idareciler) çelişkili mevki (orta düzey idareciler), çelişkili mevki (teknokratlar), çelişskili mevki (ustabaşı/bant denetçileri), proletarya, çelişkili mevki (yarı bağımsız işçiler) küçük burjuvazi ve küçük işverenlerden oluşan toplumsal sınıflar bulunmaktadır (Koşar, 2016: 43-44).

\section{Kaynakça}

Althusser, L. (2014). İdeoloji ve Devletin İdeolojik Aygıtları. (A. Tümertekin, Çev.) İstanbul: İthaki.

Aslan, Z. (2012) Geçmişten Bugüne Eleştirel Bir Orta Sınıf Değerlendirmesi. Toplum ve Demokrasi, 6 (13-14), 55-92.

Baltacı, A. (2018). Nitel Araștırmalarda Örnekleme Yöntemleri ve Örnek Hacmi Sorunsalı Üzerine Kavramsal Bir İnceleme. Bitlis Eren Üniversitesi Sosyal Bilimler Enstitüsü Dergisi, 7(1), 231-274.

Baudrillard, J. (2013). Tüketim Toplumu: Söylenceleri/Yapıları. (H. Deliceçaylı ve F. Keskin, Çev.) İstanbul: Ayrıntı.

Baudrillard, J. (2014). Nesneler Sistemi. (O. Adanır ve A. Karamollaoğlu, Çev.) İstanbul: Boğaziçi Üniversitesi.

Berger, A. A. (2014). Kültür Eleştirisi Kültürel Kavramlara Giriş. (Ö. Emir, Çev.) İstanbul: Pinhan.

Bocock, R. (1997). Tüketim. (İ. Kutluk, Çev.) Ankara: Dost. 
Bourdieu, P. (1986). The Forms of Capital. Handbook of Theory and Research for the Sociology of Education. John G. Richardson (Ed.), Handbook of Theory and Research for the Sociology of Education, New York: Greenwood, 241258, https://faculty.georgetown.edu/irvinem/theory/Bourdieu-Forms-ofCapital.pdf adresinden 26.06.2018 tarihinde edinilmiştir.

Bourdieu, P. (1995). Pratik Nedenler. (H. Tufan, Çev.) İstanbul: Kesit.

Bourdieu, P. ve Chartier, R. (2014). Sosyolog ve Tarihçi. (Z. Karaca, Çev.) İstanbul: Açılımkitap.

Cengiz, S. A. (2005). Modernizm, Otomobil Kültürü ve Reklam: Otomobil Reklamları ile Kurulan Evren. Doktora Tezi, Ankara Üniversitesi, Ankara.

Çelebi, V. (2013). Michel Foucault'da Bilgi, İktidar ve Özne İlişkisi. Sosyal ve Beşeri Bilimler Dergisi, 5(1), 512-523.

Çınar, R. ve Çubukçu, İ. (2009). Tüketim Toplumunun Şekillenmesi ve Tüketici Davranışları-Karşılaştırmalı Bir Uygulama. Atatürk Üniversitesi Sosyal Bilimler Enstitüsü Dergisi, 13 (1), 277-300.

De Certeau, M. (1990). Gündelik Hayatın Keşfi I: Eylem, Uygulama ve Üretim Sanatları. (L. A. Özcan, Çev.) Ankara: Dost.

Demez, G. (2009). Sinıfsal ve Bireysel Kimlik Oluşumunda Beden Sorunu: Habitus. Toplumbilim, 24, 17-25.

Eagleton, T. (2011). Ídeoloji ve Ídeolojinin Batı Marksizm'indeki Serüveni. Slavoj Zizek (Ed.) Ídeolojiyi Haritalamak (S. Kibar, Çev.). Ankara: Dipnot, 267-340.

Eagleton, T. (2015). Ídeoloji. (M. Özcan, Çev.). İstanbul: Ayrıntı.

Ergur, A. (2012). Hermetik Yaşam Döngüsünün Kuruluşu: Sanayi-Sonrası Yaşam Biçimleri, Tüketim Örüntüleri ve Kentle Steril Temas Yordamları. ILETI-Ş-IM, Özel Sayısı 2, 11-67.

Eyüpoğlu, A. (03.05.2012). “Türkiye'nin 'SES'i Değiști”, Sabah Gazetesi, http://cadde. milliyet.com.tr/2012/05/03/YazarDetay/1535492/turkiye-nin-ses-i-degisti adresinden 10.07.2018 tarihinde edinilmiștir.

Featherstone, M. (2013). Postmodernizm ve Tüketim Kültürü (M. Küçük, Çev.) İstanbul: Ayrıntl.

Fromm, E. (2002). Yeni Bir İnsan-Yeni Bir Toplum (N. Arat, Çev.). İstanbul: Say Yay.

Goddard, A. (1998). The Language of Advertising. London: Routledge.

Göker, E. (2014). Ekonomik İndirgemeci mi Dediniz?. Güney Çeğin (Ed.), Ocak ve Zanaat: Pierre Bourdieu Derlemesi. İstanbul: İletişim, 277-302.

Heywood, A. (2015). Siyasi İdeolojiler (L. Köker, Çev.) Ankara: BB101.

Işık, E. (1998). Beden ve Toplum Kuramı. İstanbul: Bağlam.

Jameson, F. (2008). Postmodernizm ve ya da Geç Kapitalizmin Kültürel Mantığı. (N. Plümer ve A. Gölcü, Çev.) Ankara: Nirengi.

Karatekin, U. (2009). Sosyal Sinıflar İçinde Mesleklere Göre Tüketicilerin Otomobil Alma ve Kullanma Alışkanlıkların Etkisinin İncelenmesi. Yüksek Lisans Tezi, Süleyman Demirel Üniversitesi, Isparta. 
Kawamura, Y. (2016). A Viewing Experiment on the Effects of Advertising Story. Journal of Robotics, Networking and Artificial Life, 3 (2), 92-95.

Koşar, A. (2016). Erik Olin Wright'ın Sınıf Analizinin Eleştirisi. Teori ve Eylem, 1, 3057.

Koşar, A. (3 Şubat 2017). Poulantzas'ın Sınıf Analizinin Eleștirisi-2. Teori ve Eylem Dergisi, ｈttp://teoriveeylem.net/2017/02/poulantzasin-sinif-analizininelestirisi-2/\#_ftn1 adresinden 25.06.2018 tarihinde edinilmiştir.

Kotler, P. (2002). Marketing Management, Millenium Edition. Boston: Pearson Custom Publishing.

Köse, H. (2016). Bourdieu Düşüncesinde Tahakküm-İtaat İlişkisi ve Sosyo-Politik Beden. ILEF, 3 (2), 173-199.

Lefebvre, H. (2007). Modern Dünyada Gündelik Hayat (I. Gürbüz, Çev.). İstanbul: Metis.

Lefebvre, H. (2013). Gündelik Hayatın Eleștirisi II: Gündelik Hayat Sosyolojisinin Temelleri (I. Ergüden, Çev.). İstanbul: Sel.

Lukacs, G. (1998). Tarih ve Sınıf Bilinci. (Y. Öner, Çev.) İstanbul: Belge.

Marx, K. ve Engels, F. (1976). Seçme Yapıtlar I (M. Ardos vd. Çev.) Ankara: Sol.

Marx, K. (1990). Kapital: Ekonomi Politiğin Eleștirisi III. (A. Bilgi, Çev.). Ankara: Sol.

Nas, A. (2015). Kadına Yönelik Simgesel Şiddet Aracı Olarak Temizlik Ürünleri Reklamlarının Eleştirel Analizi. Akdeniz Üniversitesi İletişim Fakültesi Dergisi, 24, 11-30.

Odabaşı, Y. (2013). Tüketim Kültürü: Yetinen Toplumdaki Tüketen Topluma. İstanbul: Sistem.

Özer, Ö. (2011). Haber Söylem İdeoloji. Konya: Literatürk.

Özgür, A. Z. (1996). Reklam Filmlerinde Görülen Kadınların İşlevsel Rolleri. Kurgu Dergisi, 14, 233-240.

Peffer, R. G. (2001). Marksizm, Ahlak ve Toplumsal Adalet. (Y. Alogan, Çev.) İstanbul: Ayrintl.

Ritzer, G. (2011). Büyüsü Bozulmuş Dünyayı Büyülemek. (Ș. S. Kaya, Çev.) İstanbul: Ayrintı Yayınları.

Sancar, S. (2014). İdeolojinin Serüveni: Yanlış Bilinç ve Hegemonyadan Söyleme. Ankara: İmge.

Smith, P. (2007). Kültürel Kuram (S. Güzelsarı ve İ. Gündoğdu, Çev.) İstanbul: Babil.

Sözen, E. (2014). Söylem: Belirsizlik, Mübadele, Bilgi/Güç ve Refleksivite. Ankara: Birleşik Yayınları.

Särngren, E. (2006). The Importance of Appearance: A study of the Importance of Appearance when Attending a Job Interview. https://gupea.ub.gu.se/ bitstream/2077/2582/1/06-40.pdf adresinden 11.07.2018 tarihinde edinilmiştir. 
Şentürk, Ü. (2012). Tüketim Toplumu Bağlamında Boş Zamanların Kurumsallaştırdığı Bir Mekân: Alışveriş Merkezleri (AVM). Pamukkale Üniversitesi Sosyal Bilimler Enstitüsü Dergisi, 13, 63-77.

Teddlie, C. ve Yu, F. (2007). Mixed Methods Sampling: A Typology with Examples. Journal of Mixed Methods Research, 1(1), 77-100.

van Dijk, T. A. (2015). Critical Discourse Analysis. Deborah Tannen ve diğerleri (Ed.) The Handbook of Discourse Analysis. West Sussex: John Wiley \& Sons, 466-485.

Veblen, T. (2014). Aylak Sınıfın Teorisi. (E. Günsel, Çev.) Ankara: Tutku.

Yılmaz, R. (2017). Televizyon Reklamlarında Metaleptik Kullanımların Tipolojisi. Gümüşhane Üniversitesi İletişim Fakültesi Elektronik Dergisi, 5, 691-704.

Yolcu, E. (2001). 'İyi’ Bir Reklam Filminde Aranması Gereken Özellikler. İstanbul Üniversitesi İletişim Fakültesi Dergisi, 11, 399-408.

Weber, M. (1999). Protestan Ahlakı ve Kapitalizmin Ruhu (Z. Gürata, Çev.) Ankara: Ayraç.

Weber, M. (1978). Economy and Society: An Outline of Interpretive Sociology. London: University of California.

Williamson, H. (2001). Reklamların Dili Reklamlarda Anlam ve Ídeoloji. (A. Fethi, Çev.) Ankara: Ütopya. 
